ks. Jan Słowiński

ORCID: 0000-0002-5063-260x

Uniwersytet im. Adama Mickiewicza w Poznaniu

\title{
Prawo kanoniczne w publikacjach ks. dr. hab. Jana Ślósarza
}

\section{Wprowadzenie}

Życie i dzieła ks. dr. Jana Ślósarza (1850-1917), prałata kapituły lwowskiej, stanowią przepiękną kartę historii ziemi myślenickiej przełomu XIX i xx wieku. Jako niezwykle zdolny syn małorolnego chłopa z Węglówki w Beskidzie Wyspowym, młody Jan został zauważony przez swojego stryja, bernardyna Juliana Ślósarza (1818-1899) i pokierowany do Seminarium Duchownego we Lwowie. Wyświęcony w roku 1879, wyjechał do Wiednia i tam doktoryzował się z teologii w roku 1885. Od roku 1887 podjął obowiązki adiunkta i wykładowcy teologii pastoralnej na Wydziale Teologicznym C.K. Uniwersytetu im Cesarza Franciszka I we Lwowie. Według biografów ${ }^{1}$ w roku 1901 habilitował się z tej dziedziny i wykładał przedmioty związane ze swoją specjalnością do roku akademickiego 1902/1903.

Omawiając dorobek pisarski prałata $\mathrm{z}$ Węglówki, pozostaje nam skupić się na dwóch rozprawach, które poświęcił zagadnieniom z zakresu prawa kanonicznego i teologii praktycznej. Pierwsza z nich to opublikowana w roku 1900 we Lwowie, nakładem Drukarni Katolickiej Józefa Chęcińskiego praca: O cenzurach kościelnych i ekskomunikach $w$ szczególny sposób Papieżowi

Por. H. E. Wyczawski ofm, Ślósarz Jan ks., w: Słownik teologów polskich, t. 4, red. H. E. Wyczawski ofM, Warszawa 1983, s. 304-305. 
zastrzeżonych ${ }^{2}$. Druga ukazała się w tej samej drukarni dwa lata później: Władza kluczów w św. sakramencie pokuty ${ }^{3}$. Żadna nie doczekała się powtórnego wydania, choć obie były przydatne kapłanom i wiernym z uwagi na przejrzyste zaprezentowanie rozproszonego $\mathrm{w}$ wielu dokumentach i zmieniającego się skomplikowanego prawa kanonicznego. Prawo to zostało uporządkowane i na nowo skodyfikowane w roku śmierci ks. Ślósarza.

\section{Rys historyczny kształtowania prawa kanonicznego}

Prawo kanoniczne, pojmowane jako dyscyplina naukowa, nazywana również kanonistyką, stanowi uporządkowany i odpowiednio uzasadniony systemem wiedzy służącej poznaniu i stosowaniu prawa, którym rządzi się i kieruje Kościół. Początki wyodrębniania się prawa kanonicznego z teologii wiążą się $\mathrm{z}$ przełomem dokonanym w pierwszej połowie XII wieku przez kamedułę Gracjana, nauczyciela uniwersytetu w Bolonii. To on opracował pierwszy systematyczny zbiór prawa kanonicznego.

W wieku XVI, podczas soboru trydenckiego, specjalna komisja opracowała i poprawiła poszczególne zbiory prawa kanonicznego, w wyniku czego papież Grzegorz XIII zatwierdził przygotowany przez korektorów rzymskich tekst Corpus Iuris Canonici (1582) jako urzędowy i zabronił na przyszłość dokonywania w nim wszelkich zmian.

Znajdowały się w nich przepisy prawne, które obowiązywały zasadniczo w kształcie niezmienionym do pierwszego nowoczesnego kodeksu prawa kanonicznego promulgowanego w roku 1917.

Czasy, w których przypadło prowadzić swoją działalność naukowo-dydaktyczną ks. Ślósarzowi, stanowią kolejny, przełomowy etap rozwoju prawa kanonicznego. W roku 1904 papież Pius X, w motu proprio Arduum sane munus, zadecydował o wprowadzeniu reformy systemu prawnego dla całego Kościoła. Owocem zapoczątkowanych przez niego wieloletnich prac nad ujednoliceniem skomplikowanego „prawa dekretałów” stał się promulgowany przez jego następcę, papieża Benedykta xv, Codex Iuris Canonici, w dużej mierze wzorowany na nowoczesnym kodeksie Napoleona. Obowiązywał on w Kościele powszechnym aż do roku 1983.

2 J. Ślósarz ks., O cenzurach kościelnych i ekskomunikach w szczególny sposób Papieżowi zastrzeżonych, Lwów 1900.

3 J. Ślósarz ks., Władza kluczów w św. sakramencie pokuty, Lwów 1902. 
Ksiądz Ślósarz opublikował swoje rozprawy w latach 1900 i 1902. Miało to miejsce jeszcze przed promulgacją pierwszego nowoczesnego kodeksu prawa kanonicznego, w czasach, gdy obowiązywało prawo zawarte w Corpus Iuris Canonici, Thesaurusie Kongregacji soboru oraz w wielu innych, niezwykle licznych i skomplikowanych zbiorach. Nie ulega wątpliwości, że poruszanie się w gąszczu obowiązujących przepisów prawa kanonicznego stanowiło nie lada problem dla duszpasterzy oraz wiernych pragnących żyć w zgodzie z zasadami głoszonymi przez Kościół. Wynikała stąd potrzeba opracowania podręczników przeznaczonych do użytku duchowieństwa, w których przepisy prawa kanonicznego, w połączeniu z zasadami teologii moralnej i pastoralnej, zostałyby wyłożone w sposób jasny i przejrzysty. Takimi właśnie podręcznikami praktycznymi są dwie rozprawy, które zostawił po sobie ks. Ślósarz.

\section{O cenzurach kościelnych i ekskomunikach w szczególny sposób Papieżowi zastrzeżonych}

Już we wstępie do swojej pracy ks. Ślósarz określa precyzyjnie cel, który przyświecał jej napisaniu:

Cel wypływa z potrzeby. Niezbędna potrzeba wyczerpującego podręcznika do Teologii Pasterskiej, któryby obejmował najnowsze rozporządzenia, coraz bardziej w duszpasterstwie uczuwać się daje $e^{4}$.

Chodziło więc autorowi o stworzenie monograficznego podręcznika, opartego na najnowszych źródłach i służącego pomocą kapłanom w duszpasterstwie, ze szczególnym uwzględnieniem sakramentu pokuty. Książka podzielona jest na dwie części, z których pierwsza omawia pojęcie i rodzaje kar kościelnych, druga zaś poświęcona została aktualnym ekskomunikom, których zdjęcie zostało zastrzeżone w sposób specjalny samemu papieżowi.

\subsection{O karach w ogólności}

Rozpoczynając swój wywód, ks. Ślósarz odwołuje się do słów Chrystusa zaczerpniętych z Ewangelii wg św. Jana w tłumaczeniu ks. Jakuba Wujka „Jako mnie Ojciec posłał, tak i ja was posyłam" (J 20, 21).

${ }^{4}$ J. Ślósarz, O cenzurach..., dz. cyt., s. v. 
Z tego Jezusowego posłania, nadającego apostołom $\mathrm{i}$ ich następcom potrójny urząd - nauczycielski, kapłański i królewski, czyli pasterski - wynika władza, którą Kościół sprawuje również przez nadawanie ustaw kościelnych, a także przez sądzenie i karanie winnych za ich występki. Występek zaś - kontynuuje autor - stanowi „zewnętrzne, dobrowolne przekroczenie prawa karnego, naruszające porządek społeczny"s.

Wyraźnie rozróżnia przy tym ks. Ślósarz pomiędzy grzechem, polegającym na przekroczeniu prawa naturalnego lub Bożego, a występkiem, stanowiącym przekroczenie prawa ludzkiego, dokonane na forum zewnętrznym, dobrowolnie i świadomie. Taki czyn pociąga za sobą karę, gdyż wiąże się ze szkodą wyrządzoną społeczności. W dalszej kolejności autor wyjaśnia cel kary kościelnej, którym jest nie tylko „pomszczenie występku przeciwko prawu kościelnemu, ale i poprawa przestępcy".

Dalszy ciąg pierwszej części rozprawy stanowi bardzo dokładny wykład na temat pojęcia i rodzajów kar kościelnych. Schemat wywodu w pewnym sensie się powtarza: autor najpierw podaje definicję, później zaś komentuje jej poszczególne elementy, odwołując się często do dokumentów kościelnych i doktryny kanonistycznej znanych i powszechnie poważanych autorów.

Najpierw mamy więc definicję cenzury, jako „kary kościelnej, duchownej, prywatywnej, poprawczej".

Ksiądz Ślósarz wyjaśnia, że jest to kara duchowna, gdyż zabrania używania dóbr duchownych i nakłada ją władza duchowna. Może być nałożona latae sententiae, kiedy z ustanowienia prawodawcy dotyka przestępcę ipso facto, kiedy przekracza prawo, albo ferendae sententiae, kiedy zostaje nałożona przez kompetentnego przełożonego kościelnego. Szczególną uwagę zwraca autor na kwestie związane z uporem sprawcy jako elementem koniecznym do ukarania go, a także z pewnymi okolicznościami zmieniającymi ciężar odpowiedzialności karnej. Następnie ks. Ślósarz przechodzi do opisania trzech rodzajów cenzur kościelnych: ekskomuniki interdyktu i suspensy.

W pierwszej kolejności określone zostało pojęcie ekskomuniki, jako cenzury „wyłączającej ochrzczonego z Kościoła".

Znajdujemy tu nieistniejące dziś w Kościele łacińskim rozróżnienie na ekskomunikę większą - pozbawiającą wszystkich dóbr duchownych -

\footnotetext{
J. Ślósarz, O cenzurach..., dz. cyt., s. 1.

J. Ślósarz, O cenzurach..., dz. cyt., s. 2.

J. Ślósarz, O cenzurach..., dz. cyt., s. 3.

8 J. Ślósarz, O cenzurach..., dz. cyt., s. 6.
} 
i mniejszą - pozbawiającą możliwości przyjmowania sakramentów i głosu biernego przy wyborach na beneficja i godności kościelne. Kto ściągnął na siebie ekskomunikę większą, mógł być „tolerowany” (toleratus) lub vitandus, czyli powiększył grono takich, których inni wierni zobowiązani byli unikać, jeżeli zostali imiennie ogłoszeni jako ekskomunikowani, bądź jeśli w sposób notoryczny znieważali osobę duchowną. Co do skutków ekskomuniki, autor wyjaśnia, że niezależnie od jej rodzaju nie pozwala ona przyjmować sakramentów pod karą grzechu ciężkiego, choć bez sankcji nieważności przyjętego sakramentu. Ponadto ekskomunika pozbawia „wspólnych suffragiów Kościoła”, czyli owoców mszy świętej i publicznych modlitw, choć prywatnie można modlić się za osoby ekskomunikowane. Ekskomunikowani, tłumaczy ks. Ślósarz, nie mogli również pełnić funkcji rodziców chrzestnych, a także sprawować sakramentów. Poza sakramentem pokuty, który ekskomunikowany vitandus sprawował nieważnie z powodu braku jurysdykcji, reszta sakramentów byłaby sprawowana ważnie, choć niegodziwie.

Ekskomunikowany „tolerowany” mógł natomiast sprawować sakramenty, o ile wierni o to go prosili' .

Kolejnym skutkiem ekskomuniki, o którym pisze autor, jest konieczność wyrzucenia $\mathrm{z}$ kościoła osoby określanej jako vitandus lub przerwania rozpoczętego w jego obecności nabożeństwa. Pozbawiony był także pogrzebu kościelnego. Ponadto vitandus karany był utratą wszelkiej jurysdykcji kościelnej na forum wewnętrznym i zewnętrznym, a wierni zobowiązani byli go unikać również w życiu prywatnym, zgodnie z łacińskim powiedzeniem: „Os, orare, vale, communio, mensa negatur”. A więc z ekskomunikowanym, poza pewnymi wyjątkami, nie należało rozmawiać i korespondować (os), nie wypadało modlić się z nim nawet prywatnie (orare), pozdrawiać go nawet gestem (vale), wchodzić w jakiekolwiek relacje (communio) oraz wspólnie z nim zasiadać do stołu (mensa).

Suspensa, według definicji podanej przez ks. Jana Ślósarza, stanowi cenzurę „zabraniającą duchownemu wykonywania władzy kościelnej, otrzymanej przez święcenia, officium lub beneficium"

Może być całkowita lub częściowa, czyli pozbawiająca duchownego jedynie części kościelnych funkcji. Autor w sposób bardzo rozbudowany wymienia rodzaje suspens, ich skutki oraz ewentualne konsekwencje pogwałcenia tej

\footnotetext{
9 J. Ślósarz, O cenzurach..., dz. cyt., s. 11.

${ }^{10}$ J. Ślósarz, O cenzurach..., dz. cyt., s. 17.
} 
kary kościelnej zarówno dla samego ukaranego duchownego, jak i dla wiernych, którym posługuje.

Szczególną formą opisywanego rodzaju cenzury jest nieistniejąca dziś w kanonicznym porządku prawnym suspensa ex informata conscientia. Łacińskie wyrażenie ex informata conscientia (co znaczy: wywodzące się ze świadomego sumienia) wskazuje na wyrok skazujący lub decyzję o ukaraniu podwładnego, które wynikają z osobistego przeświadczenia przełożonego, opartego na znajomości faktów lub argumentów przemawiających za podjęciem takiej decyzji. W dawnym prawie kanonicznym duchowny mógł zostać suspendowany przez swojego biskupa ex informata conscientia, jeżeli ten dowiedział się o faktach lub sytuacjach, które wymagały jego natychmiastowej interwencji. Prawo takie, ograniczone do przypadków tajnych, tłumaczy ks. Ślósarz, nadał biskupom i przełożonym zakonnym Sobór Trydencki, a podtrzymały późniejsze decyzje papieży i kongregacji rzymskich. Kodeks prawa kanonicznego z roku 1917 regulował kwestię tej formy suspensy w kanonach 2186-2194.

Ostatnim rodzajem cenzury kościelnej jest interdykt, czyli kara poprawcza „zabraniająca nabożeństw kościelnych, ss. Sakramentów i kościelnego pogrzebu"11.

Mógł on przyjmować formę miejscową, kiedy obejmował jakąś miejscowość (ogólny) lub miejsce (szczegółowy). Interdykt osobisty nakładany był na pewne społeczności (ogólny) lub poszczególne osoby (szczegółowy). Forma mieszana dotyczyła zarówno miejsca, jak i osób, niezależnie od tego, gdzie się znajdowały. Warto zaznaczyć, że w myśl ówczesnego prawa interdykt ogólny osobowy i interdykty miejscowe nie były postrzegane jako kary, lecz tylko jako pewne prywacje i z tej przyczyny obejmowały wszystkich, nawet niewinnych. Tego rodzaju kara kościelna wiązała się przede wszystkim z poważnymi ograniczeniami co do sprawowania i przyjmowania sakramentów oraz odprawiania egzekwii. Ksiądz Ślósarz w swojej rozprawie szczegółowo rozpatruje wszelkie możliwe konfiguracje interdyktu, określając, jakie sakramenty i nabożeństwa można odprawiać w przypadku objęcia osób lub miejsc karą interdyktu nałożoną przez władze kościelne. Jasny wywód i precyzyjne wypowiedzi autora z pewnością ułatwiały duchownym stosowanie skomplikowanych przepisów prawa w praktyce duszpasterskiej.

${ }^{11}$ J. Ślósarz, O cenzurach..., dz. cyt., s. 27. 


\subsection{Ekskomuniki speciali modo zarezerwowane papieżowi}

W części drugiej swojej rozprawy poświęconej wybranym aspektom kanonicznego prawa karnego, ks. Ślósarz odnosi się bezpośrednio do kar ekskomuniki, od których zwolnienie zastrzeżone zostało w sposób specjalny papieżowi na mocy aktów prawnych Stolicy Apostolskiej z lat siedemdziesiątych xIx wieku.

W ciągu stuleci rozwoju prawa kanonicznego nagromadziło się bardzo wiele ustaw karnych. Zostały one w dużym stopniu uproszczone przez Sobór Trydencki (1545-1563), ale z czasem, wraz z uchwalaniem nowych praw i znoszeniem starych, ustawy karne stały się znów bardzo liczne i skomplikowane, powodując niemałe zamieszanie wśród kanonistów, zakłopotanie moralistów i stając się często źródłem niepewności dla wiernych. Papież bł. Pius Ix, około 300 lat po zakończeniu soboru trydenckiego, postanowił zatem uprościć kanoniczny system karny, promulgując 12 października 1869 roku Konstytucję apostolską Apostolicae Sedis Moderationi. Dokument stanowił, że wraz z wejściem w życie nowego prawa moc obowiązującą zachowują jedynie kary przewidziane w nowej konstytucji. Wyjątek stanowiły cenzury Soboru Trydenckiego oraz te, które dotyczyły wyboru biskupa Rzymu, a także wewnętrznego zarządu zakonów i kongregacji. Dokument Piusa IX ogranicza się jedynie do cenzur latae sententiae i nie obejmuje innych kar kanonicznych, pozostawiając, poza cenzurami, dotychczasowe w mocy (np. depozycję, degradację, pozbawienie beneficjum, nieprawidłowości itd.).

Ksiądz Ślósarz zwraca w swoim dziele uwagę na niezwykłą doniosłość nowego dokumentu oraz na niewątpliwe uproszczenie przewidzianych w nim procedur związanych z nakładaniem i odpuszczaniem kar poprawczych. Rozpoczynając swój wywód, autor tłumaczy, co oznacza zastrzeżenie papieżowi speciali modo odpuszczenia ekskomuniki przewidzianej przez prawo. Chodzi bowiem o to, że nie wystarcza do tego ogólne upoważnienie kapłanów do rozgrzeszania i tym bardziej do znoszenia przez nich cenzur zastrzeżonych papieżowi. Należy mieć na uwadze fakt, że ewentualna próba odpuszczenia takiej kary, z wyjątkiem in articulo morits, wiązała się z popadnięciem spowiednika w karę ekskomuniki zastrzeżonej papieżowi.

Konstytucja apostolska Apostolicae Sedis, a za nią ks. Ślósarz podaje listę dwunastu cenzur, które są zastrzeżone w szczególny sposób (speciali modo) papieżowi. Te dwanaście cenzur, z wyjątkiem oznaczonej numerem $\mathrm{x}$, pochodzącej z bulli Benedykta XIV Sacramentum Poenitentiae z roku 1741, zostało zaczerpniętych z ogłaszanych przez wieki bulli In Coena Domini ${ }^{12}$. W swoim

${ }^{12}$ Nazwa wiąże się z tym, że w latach 1363-1770 co roku w Wielki Czwartek ogłaszano w Rzymie ekskomuniki dla różnych kategorii delikwentów. 
opracowaniu ks. Ślósarz dodaje do powyższych dwunastu ekskomunik trzynastą, ogłoszoną przez Piusa IX w roku 1873 na mocy Konstytucji apostolskiej Romanus Pontifex, czternastą nałożoną przez Kongregację soboru dnia 24 maja 1874 i piętnastą pochodzącą od Penitencjarii Apostolskiej - z 4 sierpnia 1876 roku.

Główną część wywodu ks. Ślósarza stanowi szczegółowe wyliczenie i omówienie każdej z piętnastu ekskomunik zarezerwowanych speciali modo papieżowi. Streszczenie całej rozprawy prałata z Węglówki przekracza ramy niniejszego przedłożenia.

Przytaczając treść papieskich ekskomunik, ks. Ślósarz dokonuje bardzo szczegółowej analizy treści zapisów umieszczonych w omawianej konstytucji Piusa IX oraz w uzupełniających ją późniejszych dokumentach. Autor tłumaczy znaczenie każdego słowa w myśl obowiązującej zasady ścisłej interpretacji przepisów prawa karnego, dając przez to czytelnikowi niezwykle przydatne narzędzie umożliwiające zastosowanie prawa w konkretnych przypadkach. Ksiądz Ślósarz nie ograniczał się ponadto do egzegezy treści omawianych ustaw papieskich, lecz w odniesieniu do poszczególnych ekskomunik uzupełniał swój wywód odniesieniami do innych dokumentów prawnych Kościoła, wydanych po wejściu w życie konstytucji Apostolicae Sedis.

Poza omówieniem przepisów prawa karnego w materii przestępstw obłożonych karą ekskomuniki zarezerwowanej speciali modo papieżowi, znajdziemy w rozprawie ks. Ślósarza szczegółowy opis procedur zwolnienia z kar poprawczych, a w szczególności z cenzur będących głównym przedmiotem rozważań. Należy zaznaczyć, że w omawianym okresie, czyli na przełomie wieków XIX i xx, nie istniało jeszcze obowiązujące dzisiaj w prawie kanonicznym klarowne rozróżnienie terminologiczne między rozgrzeszeniem a zwolnieniem $\mathrm{z}$ kary kościelnej, grzechem a przestępstwem. Niejednokrotnie dochodziło do swoistej konfuzji między porządkiem moralnym i prawnym, między zakresem dotyczącym sakramentu pokuty a zakresem zewnętrznym.

Powyższe zagadnienie poruszone zostanie w kolejnej części niniejszego przedłożenia, w nawiązaniu do drugiej książki ks. Ślósarza, poświęconej w dużej mierze sakramentowi pokuty i władzy udzielania rozgrzeszenia. Już teraz jednak, gwoli ścisłości, należy zaznaczyć, że prałat z Węglówki w swojej pierwszej rozprawie również używa terminu „rozgrzeszenie”, typowego dla porządku moralnego, na określenie zdjęcia kary kanonicznej $j^{13}$. Tłumaczy przy

${ }^{13}$ Por. Ł. Burchard, Ksztattowanie się pojęcia przestępstwa w systemie prawa kanonicznego, „Łódzkie Studia Teologiczne” 23 (2014) nr 2, s. 39-65. 
tym, że dokonuje się to głównie w sakramencie pokuty, chociaż możliwe jest również poza nim. Cennym elementem pracy jest szczegółowy opis wszystkich warunków, które musi spełnić penitent oraz spowiednik bądź kompetentny przełożony w celu ważnego i godziwego odpuszczenia kary.

W odniesieniu do ekskomunik zastrzeżonych papieżowi speciali modo ks. Ślósarz tłumaczy, że nie mogą ich odpuszczać nawet biskupi upoważnieni na mocy decyzji Soboru Trydenckiego ${ }^{14}$. Obowiązująca w roku wydania rozprawy praktyka rozgrzeszania od tych rezerwatów i cenzur została opisana w przytaczanym przez autora dekrecie Kongregacji Św. Oficjum z 23-30 czerwca 1886 roku. Według przewidzianej tam procedury, w nagłych wypadkach wolno dać spowiednikowi rozgrzeszenie z cenzur, o których mowa, gdy nie można odroczyć rozgrzeszenia bez wywołania zniesławienia lub zgorszenia (np. podczas spowiedzi przedślubnej). Jeżeli jednak rozgrzeszony w ten sposób penitent w ciągu miesiąca nie zwróci się do Stolicy Apostolskiej (sam lub przez spowiednika) z prośbą o zdjęcie kary, popada w nią ponownie. Podobnie, w myśl dekretu Kongregacji Św. Oficjum z 16 czerwca 1897roku, rzecz się ma w przypadku, gdyby dla penitenta było „bardzo przykrą rzeczą” pozostawać w grzechu ciężkim na czas niezbędny do uzyskania zwolnienia z cenzury papieskiej $^{15}$. Obowiązek listownego zwrócenia się, pod karą reincydencji, do Stolicy Apostolskiej w ciągu miesiąca od rozgrzeszenia z cenzur papieskich, ustaje w momencie, gdy ani spowiednik, ani penitent nie mogą tego dokonać z obiektywnych przyczyn (dekret Penitencjarii Apostolskiej z 9 listopada 1898 r.). Nie ma również wątpliwości - tłumaczy ks. Ślósarz - że władzę rozgrzeszania z wszystkich grzechów i kar ma spowiednik w chwili śmierci penitenta. Jeśli natomiast penitent wyzdrowieje, ciąży na nim obowiązek uzyskania zwolnienia z kary ze strony Stolicy Apostolskiej.

Na zakończenie tej części rozprawy autor instruuje czytelnika, w jaki sposób sformułować list do Penitencjarii Apostolskiej w celu uzyskania zwolnienia $\mathrm{z}$ kary zastrzeżonej w specjalny sposób papieżowi, oraz opisuje procedurę jego wysłania, a następnie zakomunikowania otrzymanej odpowiedzi zainteresowanemu penitentowi.

Podsumowując krótki szkic poświęcony rozprawie ks. Ślósarza z roku 190o, należy zaznaczyć, że stanowiła ona niewątpliwie przydatne narzędzie, które ułatwiało pracę duszpasterską kapłanom i przełożonym kościelnym zobowiązanym do praktycznego stosowania przepisów kanonicznego prawa karnego.

${ }^{14}$ Por. Ł. Burchard, Kształtowanie się pojęcia przestępstwa..., dz. cyt., s. 91-92.

${ }^{15}$ Ł. Burchard, Kształtowanie się pojęcia przestępstwa..., dz. cyt., s. 94-95. 
Niewątpliwą zaletą pracy była jej aktualność, oparcie na materiale źródłowym, a także na opracowaniach uznanych kanonistów.

\section{Władza kluczów w św. sakramencie pokuty}

Kościól, założony przez samego Chrystusa na fundamencie apostołów, ma szczególną naturę, gdyż będąc jednocześnie rzeczywistością widzialną i niewidzialną, nie ogranicza wykonywania swojej władzy tylko do wymiaru zewnętrznego (forum externum), jak w przypadku ustawodawstwa świeckiego. Gdy bowiem dla dobra ogółu wiernych konieczne jest działanie zewnętrzne i publiczne, dla dobra poszczególnych jednostek, w pewnych okolicznościach nieodzowne okazuje się działanie związane z zakresem wewnętrznym ${ }^{16}$.

Co do zasady owo forum internum, określane mianem „forum sumienia”, ma charakter sakramentalny, gdyż władza Kościoła realizowana jest tutaj w sakramencie pokuty. Jednocześnie jednak może ono również obejmować obszar pozasakramentalny, kiedy kompetentna władza kościelna wykonuje władzę poprzez udzielanie dyspens lub nakazów, warunkujących udział wiernego w określonych dobrach Kościoła.

Jak już wspomniano wyżej, w historii prawa kanonicznego rozróżnienie władzy forum internum i forum externum nie zawsze opierało się na jasnych kryteriach ${ }^{17}$.

Nie ulega wątpliwości, że kanoniczne prawo karne, służąc ochronie porządku prawnego w Kościele, należy do forum externum. Niestety, powyższa zasada, którą kanonistyka zna od bardzo dawna, nie zawsze była ściśle przestrzegana ${ }^{18}$. Jeszcze w kodeksie prawa kanonicznego z roku 1917 odnajdujemy pewne pomieszanie porządku moralnego i prawnego, szczególnie w materii dotyczącej sakramentu pokuty ${ }^{19}$. Problem pojawiał się w całej swojej powadze w ogólnej zasadzie zredagowanej w kanonie 2232, w którym ustanawia się, że kara kanoniczna wiąże winnego zarówno na forum internum, jak i forum externum.

${ }^{16}$ Por. M. A. Myrcha, Problem grzechu w karnym ustawodawstwie kanonicznym, „Prawo Kanoniczne" 29 (1986) nr 1-2, s. 45, 43-80.

${ }_{17}$ Por. M. A. Żurowski, Problem władzy i powierzania urzędów w Kościele katolickim, Kraków 1985, s. 75 .

${ }_{18}$ Por. M. A. Myrcha, Niektóre aspekty prawa karnego w Kodeksie z 1983 roku, w: Duszpasterstwo $w$ świetle nowego Kodeksu Prawa Kanonicznego, red. J. Syryjczyk, Warszawa 1985, s. 256.

19 Przykładem takiego pomieszania jest np. kan. $2195 \$ 1$ kodeksu Pio-Benedyktyńskiego, gdzie definicja przestępstwa obejmuje zewnętrzne naruszenie ustawy (violatio legis) oraz poczytalność moralną (moraliter imputabilis). 
Bardzo poważne przykłady pomieszania w omawianej materii, regulowanej przez kodeks z roku 1917, dotyczyły zwalniania z kar kanonicznych ${ }^{20}$.

Ksiądz Ślósarz swoją drugą rozprawę opublikował w roku 1902, a więc jeszcze przed wejściem w życie pierwszego kodeksu prawa kanonicznego. Nie ulega jednak wątpliwości, że również tutaj mamy do czynienia z typowym dla ówczesnej kanonistyki pomieszaniem porządku prawnego i moralnego. Trzeba jednak zaznaczyć, że autor prowadzi wywód w typowy dla siebie, jasny i podręcznikowy sposób, ułatwiający czytelnikowi zrozumienie zawiłości omawianych zagadnień. Chociaż, w przeciwieństwie do pierwszej dysertacji, Władza kluczów w św. sakramencie pokuty pozbawiona jest wstępu, to jednak nie ulega wątpliwości, że celem jej napisania było zapewnienie kapłanom i studentom teologii praktycznego instruktażu dotyczącego odpuszczania grzechów i kar kościelnych w ramach spowiedzi świętej.

Książka rozpoczyna się ogólnym wstępem poświęconym ustanowionej przez samego Chrystusa „władzy kluczów”, która w znaczeniu ogólnym - tłumaczy autor - oznacza „wszelką władzę, jaką nadał Chrystus Pan św. Piotrowi, jako głowie Kościoła i prawnym jego w papiestwie następcom, a przez nich całemu swemu Kościołowi”21.

W znaczeniu szczegółowym natomiast „rozumie się przez władzę kluczów władza zatrzymywania grzechów in foro conscientiae, co do winy i kary wiecznej w św. Sakramencie Pokuty przez rozgrzeszenie, a co do kary doczesnej częściowo lub zupełnie przez nadanie odpustów"22.

W dalszej kolejności ks. Ślósarz daje zwięzły wykład teologiczny, w którym, odnosząc się do fragmentów Pisma Świętego, orzeczeń soborów i wypowiedzi ojców Kościoła, uzasadnia posiadanie przez Kościół zdefiniowanej na początku władzy. Omawia również materię i formę sakramentu pokuty oraz wymienia warunki konieczne do udzielenia ważnego rozgrzeszenia: godność kapłańską, tzw. władzę sędziowskiej jurysdykcji oraz aprobatę biskupią. Właśnie tym ostatnim dwóm zagadnieniom poświęcone zostały kolejne paragrafy rozprawy prałata z Węglówki.

${ }^{20}$ Chodzi tu o przepisy kan. $2246 \$ 3$ : Reservationem peccati cui censura adnexa est; kan. 2250 $\$$ 2: Censuratus nequit absolvi a peccatis, nisi prius a censura absolutus fuerit; kan. 2260: Nec potest excommunicatus sacramenta recipere; kan. 2275: interdicti personaliter nequeunt sacramenta recipere; kan 2252: absolutio in periculo mortis; kan. 2254: absolutio in casibus urgentioribus; kan. 2290: suspensio poenarum vindicavarum in casibus occultis. Por. Ł. Burchard, Kształtowanie się pojęcia przestępstwa..., dz. cyt., s. 41-42).

${ }_{21}^{21}$ J. Ślósarz, Władza kluczów..., dz. cyt., s. 3.

${ }^{22}$ J. Ślósarz, Władza kluczów..., dz. cyt., s. 3. 
Aby otrzymać jurysdykcję konieczną do ważnego udzielenia rozgrzeszenia - tłumaczy ks. Ślósarz - kapłan musi posiadać „,aprobatę biskupią”, czyli prawne poświadczenie biskupa lub jego zastępcy o zdolności kapłana do słuchania spowiedzi. Chodzi tu o potwierdzenie odpowiedniego stanu wiedzy, roztropności i świątobliwości życia kapłana. Za wyjątkiem proboszcza każdy kapłan musiał wystarać się o rzeczoną aprobatę, która konieczna była nie tylko do godziwości, ale także do ważności rozgrzeszenia ${ }^{23}$. Autor omawia sposoby otrzymania aprobaty (egzamin) oraz przedstawia władzę kompetentną dla jej udzielenia, z rozróżnieniem na kapłanów diecezjalnych i zakonnych. Porusza również zagadnienie ewentualnego ograniczenia zakresu aprobaty, jak również jej odwołanie i ważność spowiedzi bez wymaganej aprobaty spowiednika w przypadku niebezpieczeństwa śmierci penitenta.

Kolejnym z wymienionych na wstępie wymogów, koniecznych do udzielenia ważnego rozgrzeszenia, jest tzw. jurysdykcja, czyli - w odniesieniu do sakramentu pokuty „władza, mocą której kapłan, jako sędzia, na drugiego jako poddanego może wydawać wyrok w rzeczach sumienia" ${ }^{\text {24. }}$.

Jest to władza, której kapłan nie otrzymuje automatycznie wraz z przyjętymi święceniami, lecz - tłumaczy autor - „nadawana jest mu przez Kościół, aby mógł sprawować władzę kapłańską względem poddanych swoich, których mu Kościół przydziela"²5.

Zgodnie z ówcześnie przyjętą doktryną sakrament pokuty sprawowany był per modum iudicii (w porządku sądowniczym), gdyż sam Chrystus polecił kapłanom rozsądzać, komu grzechy odpuścić, a komu pozostawić. Stąd też rozgrzeszenie bez otrzymanej z ramienia Kościoła jurysdykcji spowiednika byłoby, poza niebezpieczeństwem śmierci penitenta, nieważne. Ksiądz Ślósarz omawia dalej sposoby otrzymania jurysdykcji i osoby kompetentne mogące jej udzielać. Wyróżnia przy tym tzw. „jurysdykcję właściwą”, otrzymywaną na mocy prawa bądź urzędu (papież, biskup, kanonik penitencjarz, wikariusz kapitulny, proboszcz względem parafian i przełożony zakonny dla zakonników swej reguły) oraz ,jurysdykcję posłanniczą lub zleconą", czyli delegowaną przez tych, którzy posiadają jurysdykcję właściwą (poza proboszczami). W opracowaniu znajdziemy również dokładne omówienie sposobów udzielania jurysdykcji posłanniczej oraz prawa poszczególnych kategorii wiernych do wyboru własnego spowiednika. Na zakończenie tej części wywodu autor zaznacza,

${ }^{23}$ Zob. J. Ślósarz, Władza kluczów..., dz. cyt., s. 8.

${ }^{24}$ J. Ślósarz, Władza kluczów..., dz. cyt., s. 11.

${ }^{25}$ J. Ślósarz, Władza kluczów..., dz. cyt., s. 11. 
że w poszczególnych przypadkach Kościół uzupełnia brak jurysdykcji (Ecclesia supplet) dla pożytku wiernych ${ }^{26}$.

W prawie kanonicznym współczesnym ks. Ślósarzowi istniały jeszcze, zniesione dzisiaj, tak zwane „,rezerwaty”, czyli pewne kategorie grzechów, których odpuszczenie zastrzeżone było tylko niektórym kategoriom spowiedników. Rozpoczynając ten temat w drugiej części rozprawy, autor opisuje najpierw w sposób ogólny pewne ograniczenia jurysdykcji co do miejsca, czasu, osoby i grzechu. Spośród wszystkich wymienionych ograniczeń najważniejsze dotyczyło materii, czyli grzechów zastrzeżonych (rezerwatów). W tamtym czasie, zgodnie z ustanowieniami Soboru Trydenckiego (Sesja xIv, kan. 11), prawo zastrzegania sobie odpuszczania pewnych grzechów posiadał papież oraz biskupi i przełożeni zakonni. Czyniono to, jak tłumaczy ks. Ślósarz, dla podniesienia karności kościelnej przez okazanie penitentom ciężkości winy, powstrzymanie ich od tego grzechu przez utrudnienie w uzyskaniu rozgrzeszenia, a także powierzenie poprawy penitenta doświadczonym spowiednikom $^{27}$. Aby grzech mógł być zastrzeżony, musiał być śmiertelny, zewnętrzny, niewątpliwie dokonany i popełniony $\mathrm{w}$ wieku dojrzałym (po czternastym roku życia dla chłopca i po dwunastym dla dziewczyny). Jeśli chodzi o zakres obowiązywania rezerwatów, to wiernych dotyczyły zasadniczo ograniczenia z prawa powszechnego (rezerwaty papieskie) oraz te, które obowiązywały w ich własnej diecezji.

Jako pierwsze omawia ks. dr Jan Ślósarz rezerwaty zastrzeżone biskupom przez Stolicę Apostolską. Na mocy omawianej już wcześniej Konstytucji apostolskiej bł. Piusa IX Apostolicae Sedis z 12 października 1869 roku, trzy ekskomuniki latae sententiae zastrzeżono biskupom. Za autorem podajemy tłumaczony przez niego interesujący nas fragment papieskiego dokumentu:

1. Wyklinamy poważających się: duchownych wyższe święcenia mających, zakonników i zakonnice, zawierać małżeństwo po złożeniu uroczystego ślubu czystości, oraz tych wszystkich, którzy z wymienionymi osobami małżeństwo zawierać się odważają (s. 22).

2. Wyklinamy tych, którzy poronienie sprowadzają ze skutkiem (s. 25).

3. Wyklinamy tych, którzy $\mathrm{z}$ fałszywych listów Apostolskich świadomie robią użytek, albo występku w tej rzeczy są uczestnikami (s. 27).

${ }^{26}$ Zob. J. Ślósarz, Władza kluczów..., dz. cyt., s. 17-18.

${ }_{27}$ Zob. J. Ślósarz, Władza kluczów..., dz. cyt., s. 20. 
Każdą z tych wymienionych ekskomunik autor dokładnie omawia, precyzyjnie określając zarówno zakres podmiotowy, jak i przedmiotowy przestępstwa. Dokonuje tego, podobnie jak w swojej wcześniejszej pracy, w sposób bardzo klarowny, podpierając swój wywód licznymi cytatami z obowiązujących w tamtym czasie dokumentów Kościoła oraz wypowiedziami wybitnych kanonistów.

Na zakończenie tego działu ks. Ślósarz przytacza tekst czwartego rezerwatu papieskiego zastrzeżonego biskupom, a mianowicie dekretu Kongregacji soboru Vigilanti studio z 25 maja 1893 roku, na mocy którego ipso facto popadali w ekskomunikę m.in.:

księgarze i inni kupcy, którzy w jakikolwiek sposób zbierają stypendia mszalne i dają kapłanom celem odprawienia Mszy św. nie pieniądze, lecz książki lub inne towary [...] Księża podpadają ipso facto suspensie a divinis zastrzeżonej Stolicy Apostolskiej. Klerycy zaś suspensie co do przyjętych już święceń i stają się przeto niezdolnymi (inhabiles) do przyjęcia święceń dalszych ${ }^{28}$.

Wymienione powyżej i szczegółowo omówione przez autora cztery przypadki „papieskich rezerwatów” obowiązywały katolików na całym świecie. Kontynuując swój wywód, ks. Ślósarz przechodzi natomiast do rezerwatów zastrzeżonych przez biskupów na terenie ich własnej diecezji. Jak już wspomniano, cel rozprawy był wybitnie praktyczny, jest więc zrozumiałe, że autor ogranicza swoje rozważania do terenów archidiecezji lwowskiej, na terenie której działał jako duszpasterz i wykładowca uniwersytecki. Wymienia i opisuje siedem rezerwatów zastrzeżonych biskupowi na terenie archidiecezji lwowskiej ${ }^{29}$. Są to:

1. Dobrowolne zabójstwo.

2. Podpalenie budynków.

3. Spowiedź przed kapłanem niebędącym w łączności z Kościołem rzymskim.

4. Kazirodztwo w pierwszym stopniu pokrewieństwa i powinowactwa.

5. Aborcja po osiągnięciu skutku.

6. Stosunki seksualne z Żydami obojga płci oraz służenie im za mamkę.

7. Nakłanianie do grzechu nieczystego w sakramencie pokuty.

Jak rozumieć powyższe rezerwaty oraz komu i w jakich okolicznościach przysługuje prawo rozgrzeszenia wymienionych wyżej grzechów i odpuszczenia kar kanonicznych, wyjaśniał przytoczony przez ks. Ślósarza in extenso,

${ }^{28}$ J. Ślósarz, Władza kluczów..., dz. cyt., s. 29.

29 Zob. J. Ślósarz, Władza kluczów..., dz. cyt., s. 33. 
tekst dokumentu Monita pro confessariis ogłoszony Kurendą Konsystorza Metropolitalnego lwowskiego obrządku łacińskiego z 19 września 1885 roku. Autor kończy swoją rozprawę listami rezerwatów biskupich obowiązujących w diecezjach: przemyskiej, tarnowskiej i krakowskiej ${ }^{30}$, a także jedenastoma rezerwatami zakonnymi ${ }^{31}$.

\section{Zakończenie}

Prałat $\mathrm{z}$ Węglówki nie pozostawił po sobie wielu rozpraw poświęconych prawu kanonicznemu. Do dyspozycji mamy dwie, omówione w niniejszym przedłożeniu rozprawy, które dość szybko nabrały wartości historycznej. Spowodowane to było wejściem w życie pierwszego kodeksu prawa kanonicznego, którego promulgacja w roku 1917 zbiegła się w czasie ze śmiercią ks. Ślósarza. Pomimo tego należy uznać, że spuścizna naukowa, jaką autor po sobie pozostawił, stanowiła w swoim czasie istotny wkład w całokształt dorobku lwowskiego środowiska teologów i kanonistów. Nie ulega wątpliwości, że jasność wywo$\mathrm{du}$, precyzja formułowania myśli i rzetelny warsztat naukowy czyniły z dzieł ks. dr. Jana wartościowe narzędzia do praktycznego wykorzystania w pracy duszpasterskiej.

\section{Abstrakt}

Ks. dr hab. Jan Ślósarz opublikował dwie prace z zakresu prawa kanonicznego i teologii praktycznej: O cenzurach kościelnych i ekskomunikach w szczególny sposób Papieżowi zastrzeżoneonych (1900) i Władza kluczów w św . sakramencie pokuty (1902).

Obie publikacje okazały się przydatne zarówno dla kapłanów, jak i wiernych, ponieważ jasno przedstawiały przepisy prawa kanonicznego, które w owym czasie były skomplikowane i rozrzucone po wielu dokumentach. Obie publikacje dotyczyły stosowania kar kościelnych wobec duchowieństwa i świeckich. Kary te miały na celu zarówno bronić nauki Kościoła katolickiego jak i pomagać grzesznikom.

Niektóre kary były stosowane przez spowiedników, inne przez biskupów, a niektóre były zarezerwowane wyłącznie dla papieża. $Z$ powodu trudności w uzyskaniu rozgrzeszenia duchowni i świeccy powstrzymywali się od popełniania grzechów, zaś najwięksi grzesznicy byli kierowani pod opiekę najbardziej doświadczonych spowiedników. Ks. Jan Ślósarz w swoich publikacjach opisał różne grzechy i podał szczegółowe

$3^{\circ}$ Zob. J. Ślósarz, Władza kluczów..., dz. cyt., s. 39.

${ }^{31}$ Zob. J. Ślósarz, Władza kluczów..., dz. cyt., s. 40. 
instrukcje odnoszące się zarówno do duchownych jak i świeckich, a dotyczące tego jak postępować z osobą, która opełnia takie grzechy.

\section{SłOWA KLUCZOWE}

Prawo kanoniczne, Corpus Juris Canonici, ekskomunika, przestępstwo, grzech, jurysdykcja, kara naprawcza, papież, rozgrzeszenie, spowiedź

\section{Abstract}

Canon law in the publications of priest Jan Ślósarz Ph. D. (habil.)

Priest Jan Ślósarz, PhD (habil.), published two works on canon law and practical theology: O cenzurach kościelnych i ekskomunikach w szczególny sposób Papieżowi zastrzeżonych (On the church censures and excommunications reserved especially to Pope) (1900) and Władza kluczów w św. sakramencie pokuty (The power of keys in the holy sacrament of penance) (1902).

Both publications proved to be useful to priests as well as to the faithful because they presented clearly the codes of canon law, which at that time was complicated and scattered across many documents. Both publications addressed the application of ecclesiastical penalties to clergy and to laity. These penalties were intended both to protect the doctrine of the Catholic Church and to help sinners.

Some punishments were applied by confessors, other by bishops, and some were reserved exclusively for the Pope. Due of difficulties in obtaining absolution, clergy and laity restrained themselves from committing sins and the worst sinners were directed under care of the most experienced confessors. Priest Jan Ślósarz described in his publications various sins and provided detailed instructions applicable to clergy as well as to laity on how to deal with the person committing those sins.

\section{KEYWORDS}

canon law, Corpus Juris Canonici, excommunication, crime, sin, jurisdiction, correctional punishment, pope, absolution, confession

\section{BIBLIOGRAFIA}

Burchard Ł., Ksztaltowanie się pojęcia przestępstwa w systemie prawa kanonicznego, „Łódzkie Studia Teologiczne” 23 (2014) nr 2, s. 39-65.

Myrcha M. A., Problem grzechu w karnym ustawodawstwie kanonicznym, „Prawo Kanoniczne" 29 (1986) nr 1-2, s. 45, 43-80. 
Ślósarz J. ks., O cenzurach kościelnych i ekskomunikach w szczególny sposób Papieżowi zastrzeżonych, Lwów 1900, http://dlibra.kul.pl/dlibra/docmetadata? $\mathrm{id}=1670 \&$ from $=$ pubindex $\&$ dirids $=42 \& \mathrm{lp}=587$ (12.07.2018).

Ślósarz J. ks., Władza kluczów w św. sakramencie pokuty, Lwów 1902, http://dlibra.kul. $\mathrm{pl} /$ dlibra/doccontent?id=1658 (5.12.2017).

Żurowski M. A., Problem władzy i powierzania urzędów w Kościele katolickim, Kraków 1985. 
